
В РОССИЙСКОЙ ФЕДЕРАЦИИ

\section{PROSPECTS FOR THE DEVELOPMENT OF THE INSTITUTION OF INHERITANCE IN THE RUSSIAN FEDERATION}

V. Grunina

P. Ananin

Summary: The article considers the problem of legal regulation of the institution of inheritance. The current stage of development of the institution of inheritance has opened up wide open spaces for legal doctrine, within the framework of which a wide variety of positions are proposed to improve the current legislation in the field of inheritance.

Keywords: inheritance, spouses, testament, inheritance share, property.

\author{
Грунина Вероника Александровна \\ К.ю.н., дочент, Владимирский филиал РАНХ и ГС \\ при Президенте РФ \\ vgrun@rambler.ru \\ Ананьин Петр Александрович \\ К.ю.н., старший преподаватель, Владимирский \\ юридический институт ФСИН России \\ petron@rambler.ru
}

Аннотация: В статье рассматривается проблема правового регулирования института наследования. Современный этап развития института наследования открыл широкие просторы для юридической доктрины, в рамках которой предлагаются самые разнообразные позиции по совершенствованию действующего законодательства в сфере наследования.

Ключевые слова: наследование, супруги, завещание, доля наследования, имущество.

возникающих в случае смерти одного из супругов: в таком случае его доля в совместно нажитом в период брака имуществе[2]. могла перейти к его наследникам, тогда как переживший его супруг имел право претендовать только на причитающуюся ему долю. По мнению В.А. Илларионовой основной предпосылкой в данном вопросе послужило присоединение Крыма к Российской Федерации, в котором, ранее действующее гражданское законодательство допускало составление совместных завещаний, в связи с чем возникла коллизия, которая была устранена путем включения в раздел Гражданского кодекса Российской Федерации о наследовании норм о совместном завещании супругов.

Согласно ст. 1118 Гражданского кодекса Российской Федерации, «один из супругов в любое время, в том числе после смерти другого супруга, вправе совершить последующее завещание, а также отменить совместное завещание супругов» [3]. Таким образом, исходя из данной нормы, реализация совместного завещания в случае смерти одного из составивших его супругов ничем не обеспечена. В свою очередь, например, по гражданскому праву Германии, переживший супруг может изменить совместное завещание только в части, относящейся к его воле [4], что свидетельствует о том, что совместное завещание в Германии состоит из двух завещаний, составленных разными наследодателями, и объединенных исключительно в части совместного имущества [5]. Кроме того, если по российскому законодательству супруг может отменить ранее составленное совместное завещание путем совершения нового, собственного завещания, то в Германии завещание супругов имеет приоритет над завещанием одного из них: «распоряжения, 
содержащиеся в более позднем простом завещании, недействительны, если они противоречат более ранним взаимосвязанным распоряжениям» [6]. На наш взгляд, в российском наследственном праве необходимо закрепить аналогичные положения, что будет способствовать обеспечению наследственных прав обоих супругов и не нарушать волю супруга, умершего раньше другого. Для этого, абз. 5 п. 4 ст. 1118 Гражданского кодекса Российской Федерации необходимо изложить в следующей редакции: «Один из супругов в любое время, в том числе после смерти другого супруга, вправе совершить последующее завещание, а также отменить совместное завещание супругов в части, относящейся к его части в совместно нажитом имуществе».

Еще одним нововведением 2019 г. является наследственный договор. Данный договор нередко сравнивают с договором ренты на условиях пожизненного содержания с иждивением, однако между ними имеется существенное различие: в наследственном договоре момент перехода имущества к наследнику совпадает со днем смерти наследодателя, тогда как по договору пожизненного содержания с иждивением имущество переходит к приобретателю непосредственно в момент заключения договора.

Важная проблема, возникающая при заключении наследственного договора, вытекает из п. 12 ст. 1140.1 Гражданского кодекса Российской Федерации, согласно которому после заключения наследственного договора наследодатель имеет право совершать любые сделки в отношении имущества, указанного в наследственном договоре, а также распоряжаться им, даже если такие действия лишат наследников по данному договору какого-либо имущества. Отсюда следует, что наследодатель после заключения договора может завещать указанное в нем имущество иным лицам, продать его, уничтожить и т.д. Невольно возникает вопрос, имеет ли наследственный договор юридическую силу, раз в любой момент он может быть отменен в одностороннем порядке. Следует отметить, что в европейских странах имеется решение данной коллизии. Так, в соответствии со ст. 648 Гражданского кодекса Латвийской Республики, наследодатель вправе распорядиться недвижимым имуществом, выступающим предметом договора, с согласия наследника [7]. Данное положение соответствует основополагающим принципам отечественного гражданского права (в соответствии с п. 1 ст. 1 Гражданского кодекса Российской Федерации, гражданское законодательство базируется на признании равенства участников регулируемых им отношений [8]), в связи с этим, оно может быть перенято отечественным законодательством, регулирующим особенности наследственного договора. Это будет способствовать обеспечению прав обеих сторон наследственного договора, избежать лишения наследников имущества по данному договору. Аналогичное правило должно распространяться на случаи заключения наследодателем последующих наследственных договоров.

А.В. Шуваев выделяет еще одну проблему, которая может возникнуть при заключении наследственного договора - это риск ответственности по долгам наследодателя [9]. Так, при стандартном наследовании в порядке универсального правопреемства, к наследнику переходят не только права, но и обязанности наследодателя, в том числе и приобретенные им при жизни долги. Предметом наследственного договора, как правило, выступают имущество и имущественные права наследодателя взамен на иные встречные обязанности со стороны наследников. Ни для кого не секрет, что долги наследодателя не входят в интерес ни той, ни другой стороны, в связи с чем их включение в наследственный договор маловероятно. Более того, долги у наследодателя могут появиться после заключения наследственного договора. Данная проблема не имеет решения на законодательном уровне, в связи с чем считаем необходимым внести следующие изменения: в п. 12 ст. 1140.1 Гражданского кодекса Российской Федерации внести изменения, изложив его в следующей редакции: «После заключения наследственного договора наследодатель вправе совершать любые сделки в отношении принадлежащего ему имущества и иным образом распоряжаться принадлежащим ему имуществом своей волей и в своем интересе, даже если такое распоряжение лишит лицо, которое может быть призвано к наследованию, прав на имущество наследодателя. Соглашение об ином ничтожно. О совершенных сделках или распоряжении иным образом принадлежащим имуществом наследодатель обязан уведомить стороны наследственного договора. Уведомление о совершении сделки в отношении имущества, а также распоряжении наследодателем иным образом принадлежащим ему имуществом подлежит нотариальному удостоверению. Нотариус, удостоверивший уведомление о совершении наследодателем сделки в отношении имущества, а также распоряжении наследодателем иным образом принадлежащим ему имуществом, обязан в порядке, предусмотренном законодательством о нотариате и нотариальной деятельности, в течение трех рабочих дней направить копию этого уведомления другим сторонам наследственного договора».

Наконец, нельзя не упомянуть о наследственных фондах, которые представляют собой юридические лица, создаваемые в соответствии с завещанием в целях управления имуществом наследодателя как на бессрочной, так и на срочной основе, в интересах третьих лиц (выгодоприобретателей), которые могут претендовать на получение имущества, переданного в фонд, или доходов от его деятельности. Таким образом, наследственные фонды выступают наследниками, которые одновременно являются выгодоприобретателями, заинтересованными в увеличении доходов фонда от 
использования перешедшего им по наследству имущества. Подразумевается, что наследственный фонд будет осуществлять определенные сделки для достижения целей его создания. В то же время, как и любой иной фонд, наследственный фонд может не исполнить или исполнить ненадлежащим образом возложенные на него обязанности, за что российским законодательством предусмотрена ответственность. Однако, как следует из ст. 123.20-3 Гражданского кодекса Российской Федерации, выгодоприобретатель не может нести ответственность. В разрешении данной проблемы верным представляется точка зрения, предложенная Н. М. Головановым, который предлагает закрепить, что «наследственный фонд, несмотря на то, что является выгодоприобретателем от использования наследственного имущества, тем не менее, несет полную ответственность этим имуществом по своим обязательствам» [10]. Соглашаясь с данной точкой зрения, предлагаем внести в п. 1 ст. 123.20-3 Гражданского кодекса Российской Федерации следующие дополнения: «... Сделки, совершенные с нарушением этих правил, являются ничтожными. Правила настоящей статьи не распространяются на лиц, являющихся выгодоприобретателями наследственного фонда». Данным положением будет обеспечиваться воля наследодателя, которую он изложил в завещании в части образования наследственного фонда.

С.С. Цатурян выделяет проблему невозможности внесения в устав наследственного фонда коррективов и изменений после смерти наследодателя [11]. Так, при обнаружении после смерти наследодателя ошибки в уставе, либо изменении окружающей обстановки, требующей внесение в него изменений, исправления не допускаются. На наш взгляд, в законодательство должны быть внесены коррективы, согласно которым по инициативе участников наследственного фонда в его устав могут быть внесены изменения при условии их обязательного удостоверения нотариусом, удостоверившим завещание, в котором содержалось указание об образовании наследственного фонда, либо иного нотариуса, которо- му было передано данное наследственное дело.

Что касается наследования по закону, то, на наш взгляд, перспективы его развития могут произойти в направлении расширения круга наследников. Если сравнить российское законодательство о наследовании по закону и зарубежное, выявляется, что в отечественной системе очередности выделяется самое большое количество очередей - восемь. Сокращение их числа повлечет за собой ухудшение положения потенциальных наследников, а, соответственно, и нарушение их права на наследование. В то же время, несмотря на меньшее количество очередей в иных государствах, самих наследников, призываемых к наследству по закону, гораздо больше. Так, согласно Гражданскому законодательству Украины, в последнюю очередь наследования входят иные родственники наследодателя до шестой степени родства включительно, причём родственники более близкой степени родства отстраняют от права наследования родственников дальней степени родства; иждивенцы [12].

Таким образом, в России наследование по закону в дальнейшем может развиваться по пути расширения уже существующих очередей наследования за счет включения в них иных лиц более далекой степени родства (троюродные дяди, тети, бабушки, дедушки и т. д.).

В заключение хотелось бы отметить, что наследование по закону в Российской Федерации идет по пути рецепции регулирующих данную сферу общественных отношений нормативных положений иностранных государств, в первую очередь, европейских, о чем свидетельствуют, в частности, последние нововведения: введение совместного завещания супругов, наследственного договора и наследственных фондов. На наш взгляд, такие заимствования могут иметь положительные результаты, для чего, однако, требуется их тщательная проработка исходя из условий российской правовой системы.

\section{ЛИТЕРАТУРА}

1. Попова В.В. Сравнительный анализ норм российского и зарубежного законодательства о совместном завещании супругов // Право и государство: теория и практика. 2019. № 5 (173). С. 35.

2. Семейный кодекс Российской Федерации от 29.12.1995 № 223-Ф3 // Собрание законодательства РФ, 01.01.1996, № 1, ст. 16.

3. Гражданский кодекс Российской Федерации (часть третья): Федеральный закон от 26.11.2001 № 146-Ф3.

4. Гражданское уложение Германии: Вводный закон к Гражданскому уложению. - 4-е изд., перераб. М.: Инфотропик Медиа, 2015. С. VIII - XIX, 1715 C.

5. Попова В.В. Сравнительный анализ норм Российского и зарубежного законодательства о совместном завещании супругов. С. 34.

6. Новичкова Ю.А., Чеснокова Ю.В. Совместное завещание супругов: проблемы и перспективы развития // Конкурс молодых ученых: сборник статей Международного научно-исследовательского конкурса. 2020. С. 193.

7. Гражданский кодекс Латвийской Республики от 23 января 1937 г. [Электронный ресурс]: http://law.edu.ru/norm/norm.asp?normID=1260168\&sublD=1001 23791,100123794,100125693,100125917,100125927\#tехt (Дата обращения: 20.03.2020).

8. Гражданский кодекс Российской Федерации (часть первая): Федеральный закон от 30.11.1994 № 51-Ф3 // Собрание законодательства РФ, 05.12.1994, № 32 , ст. 3301. 
9. Шуваев А.В. Правовое регулирование наследственного договора // Актуальные проблемы частного и публичного права (к юбилею кандидата юридических наук, профессора, заслуженного юриста Российской Федерации М.Г. Марковой) Материалы межвузовской научно-практической конференции. Составитель В.А. Максимов. 2019. С. 185.

10. Голованов Н.М. Проблемы правового регулирования наследственного фонда в Российской Федерации // Евразийский союз ученых. 2020. № 1-6 (70). С. 23.

11. Цатурян С.С. Наследственные фонды: новый институт наследственного права РФ // Приоритетные направления развития науки и образования: сборник статей Х Международной научно-практической конференции: в 2 ч.. 2020. С. 103.

12. Гражданский кодекс Украины от 16.01.2003 г. №435-IV. [Электронный ресурс]: https://meget.kiev.ua/kodeks/grazdanskiy-kodeks/glava-86/ (Дата 0бращения: 21.03.2020).

(с Грунина Вероника Александровна (grun@rambler.ru), Ананьин Петр Александрович (petron@rambler.ru).

Журнал «Современная наука: актуальные проблемы теории и практики»

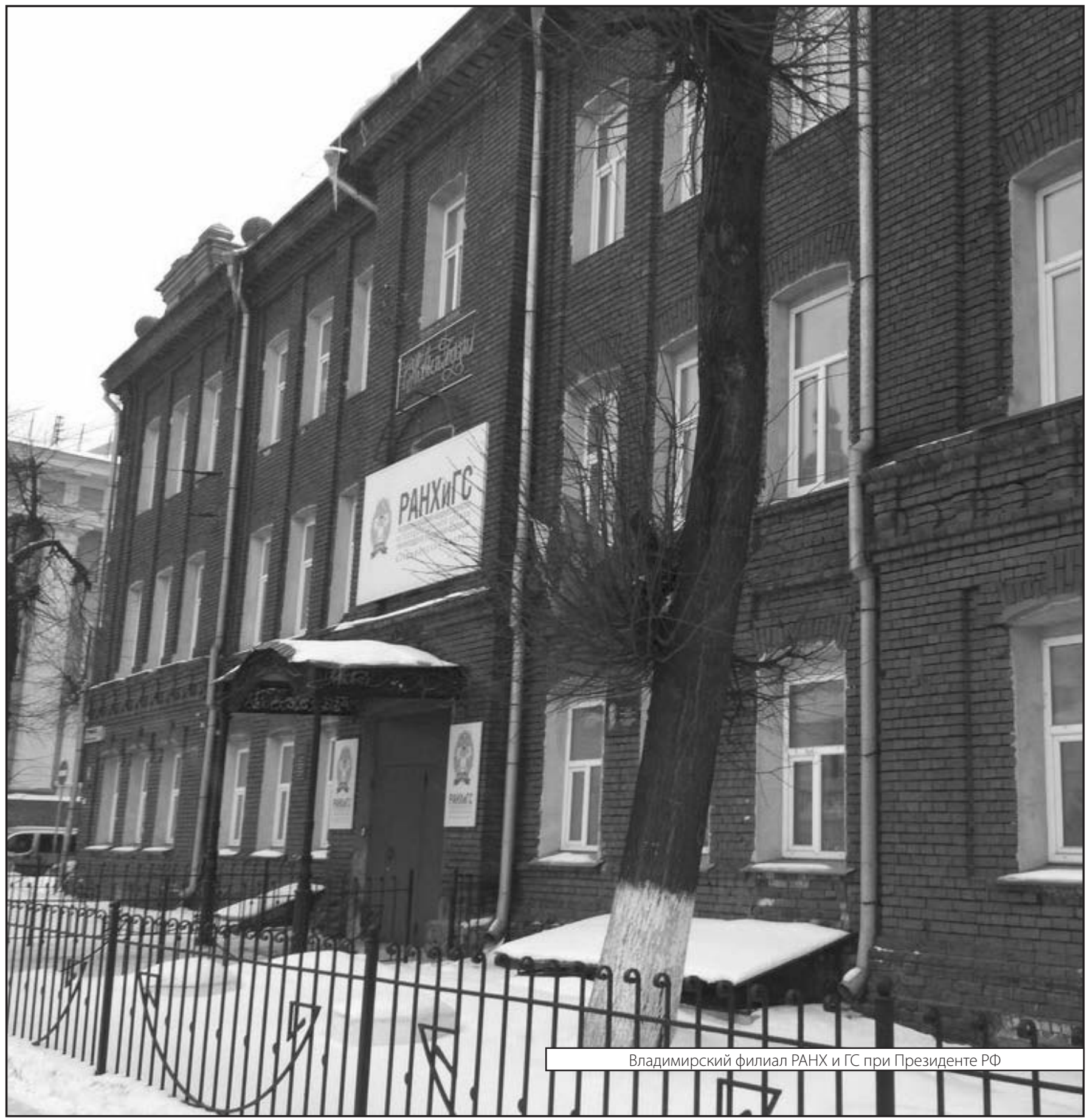

